\title{
Does more energy consumption support economic growth in net energy-importing countries?
}

\author{
Ömer Esen
}

Department of Economics, Mus Alparslan University, Mus, Turkey, and

$$
\text { Metin Bayrak }
$$

Department of Finance, Kyrgyz-Turkish Manas University, Bishkek, Kyrgyzstan

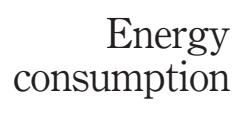

Received 3 June 2016

\begin{abstract}
Purpose - This study aims to examine the effects of energy consumption on economic growth by means of a panel data analysis of 75 net energy-importing countries for the period 1990 to 2012.

Design/methodology/approach - For the purpose of the analysis, the countries are classified into two groups, and each group is then classified into subgroups. The first group is formed based on the energy import dependence of the countries and is classified into two subgroups according to whether their dependence is greater than or less than 50 per cent. The second group is formed based on the income level of the countries and is classified into four subgroups, specifically, low-income economies, lower-middle-income economies, upper-middle-income economies and high-income economies.

Findings - The findings obtained for both panel data and for each country indicate that there is a positive and statistically significant relationship between energy consumption and economic growth over the long term such that energy consumption contributes more to economic growth as the import dependence of the country decreases. Moreover, the effect of energy consumption on economic growth decreases as the income level of the country increases. This indicates that the efficient use of energy is as important as energy consumption, which is regarded as an important indicator of economic development.

Originality/value - The authors expect that these findings will make a valuable contribution to the results of future studies, as they analyze the relationships among the variables by including the energy intensities of the countries.
\end{abstract}

Keywords Economic growth, Energy consumption, Panel data analysis, Net energy importers

Paper type Research paper

\section{Resumen}

Propósito - Este estudio examina los efectos del consumo de energía en el crecimiento económico, mediante un análisis de datos de panel de 75 países importadores netos de energía para el período 1990-2012.

Diseño/metodología/enfoque - A los efectos del análisis, los países se clasifican en dos grupos y cada grupo luego se clasifica en subgrupos. El primer grupo se forma en base a la dependencia de los países en materia de importación de energía y se clasifica en dos subgrupos según su dependencia sea superior o inferior al 50\%. El segundo grupo se forma sobre la base del nivel de ingresos de los países y se clasifica en

(c) Ömer Esen and Metin Bayrak. Published in Journal of Economics, Finance and Administrative Science. Published by Emerald Publishing Limited. This article is published under the Creative Commons Attribution (CC BY 4.0) licence. Anyone may reproduce, distribute, translate and create derivative works of this article (for both commercial and non-commercial purposes), subject to fullattribution to the original publication and authors. The full terms of this licence may be seen at http://creativecommons.org/licences/by/4.0/legalcode

JEL classification - C33, O13, Q43

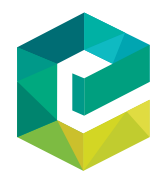

Journal of Economics, Finance and Administrative Science Vol. 22 No. 42,2017
pp. $75-98$ 
JEFAS

22,42

76 cuatro subgrupos: economías de ingresos bajos, economías de ingresos medios-bajos, economías de ingresos medios-altos y economías de ingresos altos.

Hallazgos - Los hallazgos obtenidos, tanto para los datos de panel como para cada país, indican que existe una relación positiva y estadísticamente significativa entre el consumo de energía y el crecimiento económico a largo plazo, de modo que el consumo de energía contribuye más al crecimiento económico a medida que disminuye la dependencia de las importaciones del país. Además, el efecto del consumo de energía en el crecimiento económico disminuye a medida que aumenta el nivel de ingresos del país. Esto indica que el uso eficiente de la energía es tan importante como el consumo de la misma, que se considera un indicador importante del desarrollo económico.

Originalidad/valor - Los autores esperan que estos hallazgos aporten una valiosa contribución para estudios futuros, ya que analizan las relaciones entre las variables mediante la inclusión de las intensidades de los países.

Palabras clave - Consumo de energía, Crecimiento económico, Importadores netos de energía, Panel de datos

Tipo de artículo - Artículo de investigación

\section{Introduction}

Energy plays an important role in the lives of humans and in the activities of the economy, both as a scale of economic and social development and as a basic humanitarian need. Therefore, energy consumption per capita of a country is regarded as an important indicator of economic development. In today's world, energy is not only considered to be a production input but is also regarded as a strategic commodity that constitutes the basis for international relations and shapes the world economy and politics. The conditions under which energy is procured and the problems experienced during the procurement process directly affect competition at both the national and international levels; these conditions also shape the production structures of the countries and constitute one of the main indicators of basic economic variables. For all of these reasons, energy is one of the most important issues in today's world.

The mechanization of production and the emergence of mass (serial) production methods following the industrial revolution in the late eighteenth century resulted in an increased demand for energy. This, in turn, caused the production process and the capacity of a country to become increasingly dependent on energy and energy-based inputs. Although energy is not the only input that determines the level of production and the degree of economic development of a country, it is highly important for economic growth. It is only by means of consuming a certain amount of energy that countries can achieve a certain level of economic growth. In today's world, it does not seem possible to produce goods and services, sustain the production process or offer these goods and services to consumers in an appropriate way without energy (IAEA, 2009). Therefore, any interruption in the procurement of energy, which is a highly important input used in every phase of production, or any failure to meet the energy demand increase of increasing production under favorable conditions may cause a bottleneck in the economy (Smulders and De Nooij, 2003). Thus, countries should procure a sufficient amount of energy in a cost-effective, quality-conscious, safe manner - without any interruption - to achieve sustainable growth goals and improve their living standards.

It is well known that energy demands of countries are increasing with each passing day, but the resources used to generate energy are limited in both amount and range. Moreover, the distribution of energy resources around the world is not balanced, as some regions have more reserves compared to others in terms of both amount and range. Such an uneven distribution of energy resources is not only valid for the reserves but also for the consumption levels, and as such, there is a large imbalance between not only regions but also countries with respect to the use of energy resources around the world. This forces 
countries into a great struggle to access these resources under reasonable, reliable and sustainable conditions to meet their increasing energy demands. The scarcity of energy resources around the world begets the emergence of a great competition for energy procurement among the countries.

The energy demands of countries are increasing every day, depending on their growing economies and their changing socio-economic structures. Their failure to increase energy generation despite their increasing energy consumption results in an important problem known as an energy deficit. If an economy experiences a lack of energy resources, it will either choose to accept "low economic growth through production with the existing energy resources" or attempt "to increase growth by meeting the uncovered part of energy demand through imports". The price and direct or indirect procurement of energy affect the production structures of countries as well as their budget balance and competitiveness in the national and international markets. They are also the major indicators of many economic problems, such as the current account deficit. For all of these reasons, energy has become one of the most important issues in the world. Moreover, as energy resources are under the control of a limited number of countries, the potential problems that these countries may have can jeopardize the security of energy procurement, which constitutes another problem together with the cost of consumption incurred by the energy resources used to meet the increasing demands. Such ambiguities in the procurement of energy cause welfare loss and failure to achieve sustainable growth. Thus, timely and sufficient procurement of highquality energy at an affordable price is of great importance, as it ensures the operation of the economy and leads to sustainable growth. However, the effective and efficient use of the procured energy is no less important.

The important role of energy as a production input had been disregarded until the oil crisis of the 1970s. Following this period, energy was considered, together with labor and capital, to be a factor of production, and the number of studies on energy and energy-related problems began to increase. These studies address the energy issue from different perspectives. Some of the studies in the economics literature regard energy as a technical problem, and thus, they assume that by improving existing production (consumption) technologies or by providing new technologies, it is possible to meet the higher energy demands of today, as compared to those of the past, with the same amount of energy used by economies in production or by humans in their daily lives (Kavrakoğlu, 1981; Mankiw, 2010; Krugman and Wells, 2010). According to this assumption, the problem of increased demand will be eliminated as technology advances. Other studies regard energy as an economic problem and argue that the increased energy demand problem leads to exorbitant oil prices that increase the prices of other energy resources, making energy a difficult-toacquire commodity (Kavrakoğlu, 1981). This assumption implies that the energy problem will be solved if oil, whose cost does not exceed $\$ 10$ per barrel, is used as an energy source that does not generate high profits. Other studies suggest that energy problems result from the gradual depletion of energy resources, especially primary resources, around the world (Kavrakoğlu, 1981). As the prices of depleted commodities increase, it becomes increasingly more difficult to find these resources. Therefore, the fact that known oil reserves now face the risk of depletion within approximately 50 years, production and consumption make this energy resource expensive and difficult to find. Due to the rapid depletion of oil reserves with each passing day, it is thought that this problem can be mitigated in the short term and completely solved in the long term, provided alternative energy sources are mobilized.

After the oil crises of the 1970s, the relationship between economic growth and energy consumption became a common research subject for theoretical and empirical studies, as well as one of the major issues of debate in the economics literature. Some of the empirical 
JEFAS

22,42

findings reveal that energy consumption contributes to economic growth, while others find that energy consumption has no effect on economic growth or that its effect is so small that it can be ignored. A review of the literature on the effects of energy consumption on economic growth indicates that some studies regard energy as a key input that is used in all phases of production and as a resource consumed as an output for increasing the welfare level (Stern, 2000; Shiu and Lam, 2004; Altinay and Karagol, 2005; Odhiambo, 2009; Apergis and Payne, 2010; Iyke, 2015). This hypothesis, referred to as the growth hypothesis in the literature, claims that energy is one of the key indicators of economic growth. Those who oppose this hypothesis argue that energy plays a minimal or neutral role in economic growth and propose their assumption under the name of the neutrality hypothesis. There are a considerable number of studies whose results favor the neutrality hypothesis (Akarca and Long, 1980; Yu and Hwang, 1984; Cheng, 1995; Hondroyiannis et al., 2002; Altinay and Karagol, 2004; Ozturk et al., 2010). According to this hypothesis, policies intended to reduce energy consumption have no effect on economic growth.

Previous studies view the energy consumption level as an indicator of development and argue that a country's production is based on the amount of energy it consumes and that, similarly, it achieves a high level of welfare to that extent. However, development should be based on the ability to create greater economic value with less energy, i.e. delivery of the same amount of production with less energy, rather than being based on energy consumption rates. This is evidenced in the development levels of countries, especially in those countries with a production structure that is dependent on energy imports, as increasing energy consumption can disrupt the macroeconomic equilibrium, which then makes the economy vulnerable to external shocks. In underdeveloped or developing countries, inefficient use of energy in terms of both production and consumption causes the already high current account deficit to increase further, causing these economies to be more vulnerable to external shocks related to energy procurement and price volatility. Though it is well known that energy consumption is important for economic growth, empirical studies in the literature provide little information about whether such importance changes depending on the import dependence or the income levels of the countries.

This study aims to empirically examine the effect of energy consumption on economic growth in 75 net energy-importing countries. Consistent with this purpose, we put forth that this study constitutes a significant contribution to the literature on the foundations of economic growth in countries dependent on external resources for energy. Moreover, the study aims to contribute to enhancing the energy consumption growth debates by establishing solidly grounded theoretical and empirical bases. In the first stage of the study, we review the theoretical and empirical literature that focuses on the relationship between energy consumption and economic growth and the effect of the former on the latter. In the subsequent sections, we examine the factors that strengthen or reduce the linkage between energy consumption and economic activities, and then examine the effects of energy consumption on economic growth for the period 1990 to 2012 by classifying 75 net energyimporting countries into subgroups. In the final stage, the findings are compared with the findings of other studies in the literature.

\section{Determinants of the relationship between energy consumption and economic growth}

With the emergence of the industrial revolution, countries' energy use increased significantly and has continued to rise. Energy is of critical importance for countries, as it is a key input for achieving economic, social and industrial development and for increasing the welfare level. However, while there have been extensive debates on the energy consumption 
trends of both developed and developing economies since the oil crisis of the 1970s, they do not disregard the importance of energy for production and daily consumption (Stern and Cleveland, 2004).

If energy constitutes a relatively small part of the total production cost or is not a primary input when compared with other production inputs, an interruption in the procurement of energy or an increase in its price will not have much effect on the economy (Mallick, 2007). Conversely, if energy is a highly important input in the production process or is among the basic humanitarian needs, potential problems in its supply or exorbitant energy prices will cause serious problems in both production and the daily lives of consumers. In this sense, determining and examining the factors that strengthen or reduce the linkage between energy use and economic activities is of critical importance for sustainable growth.

Determining and examining the factors that strengthen or reduce the linkage between energy use and economic activities is extremely important, as doing so adds clarity to the issue. Accordingly, the general production function used to demonstrate this relationship is written as follows (Stern and Cleveland, 2004; Stern, 2004):

$$
\left(Q_{1}, \ldots, Q_{m}\right)^{\prime}=f\left(A, X_{1}, \ldots, X_{n}, E_{1}, \ldots, E_{p}\right)
$$

In this functional equation, $Q_{i}$ indicates various outputs, such as manufactured goods and services, that are included in the model as dependent variables; $\mathrm{X}_{i}$ represents various inputs, such as capital and labor; and $\mathrm{E}_{i}$ indicates different energy inputs, such as coal and oil. Additionally, A represents the state of technology as defined by the total factor productivity indicator. In this sense, the relationship between energy use and an aggregate of output, such as GDP, is affected by the following variables (Stern and Cleveland, 2004):

- substitution-complementarity between energy and other inputs;

- technological change and efficient use of energy;

- shifts in the composition of the energy input; and

- shifts in the composition of GDP (output).

In addition to these variables, there is a widespread debate in the literature asserting that the pricing factor in energy generation and consumption affects the relationship between energy and output (Berndt and Wood, 1975).

\subsection{Energy and other production inputs: substitution-complementarity relationship}

Investment and production are extremely important economic activities in terms of wealth, development and welfare for both developed and developing countries. Throughout the history of economics, numerous studies have examined production, production structure and economic growth, and they all have sought answers to questions such as, "which goods must be produced by the countries?" and "to what extent and how are they to be produced?". Thus, production and ensuring the sustainability of this production are important to meet the needs of the communities and increase the welfare level.

A country aiming to achieve maximum utility is expected to use the relatively abundant factor of production that it exhibited during the production process. In this case, the substitute or complementary relationship between production inputs leads to the question of which input should be used most often during the production process. The production inputs that are used to achieve a certain level of production are called complements, and therefore, one of these complements cannot be used without the other. The inputs that can be 
JEFAS

22,42

used in place of each other during the production of the same level of output are called substitute or rival production inputs. For a given level of technology, the production inputs such as energy and capital and labor used per unit of economic output can be used together during production or can be used as substitutes for each other, provided that the production level remains constant. The complementary relationship between energy and other production inputs means that if energy prices increase and energy consumption is reduced, the demand for capital and labor services will also decrease, thus leading to the production of a lower level of output. However, substitution means that the demand for capital and labor services will increase and that the level of output will not be low (Hudson and Jorgenson, 1974; Berndt and Wood, 1975; Asaduzzaman, 1995; Huang et al., 2006).

In general, energy and other inputs are found to be complements based on the time-series results, while the cross-sectional results indicate that they act as substitutes. Thus, it is inferred that energy and other factors of production act more as complements in the short term and more as substitutes in the long run (Gibbons, 1984; Apostolakis, 1990; Ebohon, 1996). In the short term, the energy required to operate the machinery and equipment used for production makes energy and other factors of production complementary inputs. In the long term, by means of the use of new highly energy-efficient machines and processes introduced with the advancement of technology, energy products can, to some degree, substitute for other production inputs, or the labor/capital-intensive products can be produced with less capital/labor (Asaduzzaman, 1995). Furthermore, the energy price changes affect not only the demand for energy but also the capital formation and use of labor (Apostolakis, 1990). Though an increase in the energy prices does not easily change the existing production structure of an economy in the short term, such an increase results in costlier production and investments. As the production and investment volume is reduced, all production inputs are also reduced, thus indicating that energy and other factors of production complement each other. Accordingly, the substitution of energy with other production inputs is not possible in the short term (Aydın, 2010). However, substitution among production inputs is possible in the long term, as the production structure can be easily changed over the long term. As the prices of energy products increase, the relative price of energy also increases compared to other production inputs. In this case, a less energy-intensive and more labor/capital-intensive production structure may be preferred. Such a development in production reduces the use of high-priced energy and increases the use of other production inputs with relatively low prices, thus indicating that energy and other inputs can be substituted with each other (Gibbons, 1984; Webster et al., 2008).

Numerous studies examine whether there is a substitution or complementary relationship between production inputs and the extent to which they can substitute for each other. However, to date, no common ground has been reached (Hudson and Jorgenson, 1974; Iqbal, 1986; Apostolakis, 1990; Thompson and Taylor, 1995; Ebohon, 1996; Frondel and Schmidt, 2002; Koetse et al., 2008). Studies suggesting the existence of a substitute or a complementary relationship between energy and other factors of production generally argue that energy and other factors of production act more as complements in the short run, but act more as substitutes in the long term when the technology or production structure can be easily altered (Gibbons, 1984; Apostolakis, 1990; Aydın, 2010). However, there are also studies suggesting that there is a substitution relationship between energy and other production inputs (capital) when the energy intensity is low, and a complementary relationship when the energy intensity is high (Huang et al., 2006).

Stern (2010) argues that energy can either restrict or contribute to production and economic growth, depending on the convenience of energy procurement and the level of existing technologies. However, a considerable portion of the production and consumption 
activities require energy as an input, which indicates that other production inputs are, for the most part, in a complementary relationship with energy. In conclusion, given that economic growth is a long-term phenomenon, complementarity is much more on the forefront than substitution with respect to the relationship between energy and other production inputs.

\subsection{Energy efficiency and technological change}

Energy efficiency, i.e. the efficient use of existing energy, can be defined as the use of scarce and valuable resources that are primary inputs in all economic activities in a way to achieve maximum utility for a given level of technology. In short, energy efficiency means obtaining the maximum added value possible with the energy used in production or consumption. Herein, energy efficiency not only refers to the consumption process of the required energy but also means putting energy into final use with minimum loss and maximum efficiency during a long-term process that includes both the production and distribution phases. It must be emphasized that an energy resource obtained through the fastest and cheapest way possible without high investment costs is an energy resource that is used efficiently. The efficient use of energy in the production, distribution and consumption phases provides the opportunity to engage in the same amount of work while using less energy and without decreasing the welfare level or the quality and quantity of production.

One of the most important indicators of efficient energy use is energy intensity, which represents the amount of energy consumed per GDP (Patterson, 1996; Boyd and Pang, 2000). Energy intensity gives an idea about how efficiently energy has been used in added-value production in an economy. High energy consumption per capita and low energy intensity is the ideal condition for development in terms of energy (EMO, 2012). This is possible through acquiring the goods and services using less energy or achieving maximum efficiency from the existing energy resources.

In a production or consumption process, as general improvements in technology or use of new technologies may reduce energy consumption per output, technical changes are closely related to energy efficiency. The autonomous energy efficiency index (AEEI), which includes technical changes, is used to measure the potential effects of technological changes on current energy efficiency in an economy. This index measures the technological changes that reduce the energy use per output independent of price changes in an economy (Bataille et al., 2006; Rivers and Jaccard, 2006; Stern, 2011). To incorporate technical changes into the process, the production function is re-formulated as follows (Stern, 2011):

$$
Q=f\left(A_{1} X_{1}, \ldots, A_{n} X_{n}, A_{E} E\right)
$$

Each input is multiplied by its own technology factor $\mathrm{A}_{i}$, and thus, the crude units of the input are converted into effective units. AE represents the index of energy that enhances technical change, and as such, it holds the use of all other inputs and their augmentation indices constant (Stern and Cleveland, 2004; Stern, 2011). Thus, an innovation that reduces the energy input for a unit of added value, for a unit of GDP or for a new development that provides energy savings, ensures the efficient use of existing energy resources in both production and consumption (Bataille et al., 2006). In this sense, energy efficiency ensures that the amount of energy required for growth can be met with less energy. Thus, the efficient use of energy is considered as an alternative energy resource.

Other than those mentioned above, many innovations and technological developments that help in achieving energy efficiency can cause a decrease in the price of the energy products by decreasing the amount of energy required for production (consumption) when 
JEFAS

22,42

the other variables are held constant. Therefore, the use of resources that have been saved beforehand in the production (consumption) of other goods and services can increase production (consumption) and, therefore, the energy demand (Saunders, 1992; Greening et al., 2000).

\subsection{Energy quality and shifts in the composition of the energy input}

The issue of energy quality or the use of good-quality energy attracts the attention of researchers due to its effects on labor and capital efficiency as well as its impact on the amount of energy required to produce a unit of GDP (Schurr et al., 1960; Stern and Cleveland, 2004; Liddle, 2012). The existing energy resources are not of the same quality, nor do they have the same level of productivity (level of energy generation). In other words, some energy resources are more productive and provide a higher level of utility in the production of economic output than do other energy resources (Stern, 2010). Energy quality refers to the amount of energy content per unit of weight or economic usefulness per heat equivalent unit of an energy resource (Cleveland et al., 2000).

Due to the changing and developing technology, the tools and materials used now consist of increasingly more high-tech products that require a considerable amount of energy, a situation that is similar to the past. On the one hand, this increases production and makes life easier for people, while on the other hand, it causes the tools used in production and consumption to be more sensitive to the quality of the energy required for operation. In the literature, electricity is viewed as the highest quality type of energy, followed by natural gas, oil, coal and wood and biofuels in descending order of quality (Stern and Cleveland, 2004). This view is supported by the typical prices of these fuels per unit of energy. Among the known energy resources, electricity tends to be the most expensive energy source, followed by other energy resources, such as oil and coal, with respect to their differences in productivity and quality (Liddle, 2012). As energy quality is not fixed over time, the composition of energy input changes accordingly over time. The history of economics indicates that there is a shift from lower-quality energy resources to higher-quality resources, which reduces the amount of energy input required to produce a unit of added value or GDP (Schurr et al., 1960; Stern and Cleveland, 2004). Moreover, the quality of energy used in production directly affects the quality of products and production. From this perspective, energy plays a key role in survival in the globalized, competitive markets of today.

\subsection{Shifts in the composition of the gross national product (output)}

The potential effects of energy use on economic growth change depending on the phases of development a country has undergone and on the economic structure of the country. Combined with economic development, the shares of industries in the gross national product change. In the earlier phases of development, economic growth is found to be primarily related to agriculture, and thus, the agricultural sector is found to contribute more to economic growth than other industries. In the later stages of development, economic growth occurs in the industrial sector, wherein existing resources are used more intensively, while the relative contribution of the agricultural sector to economic growth decreases. The economies that have completed a transition period from agriculture to industry experience a shift to services that requires relatively fewer resource-intensive activities (Stern and Cleveland, 2004; Mehrara, 2007), as service-producing economic activities require less energy and more labor (Kavrakoğlu, 1981) than do other economic activities. In this case, it is expected that the relative share of services in economic growth will increase as development increases, while the relative shares of agriculture and industry will decrease. 
We divide the sectors into three groups, namely, agriculture, industry and services. All of these industries exhibit different energy intensities (Stern and Cleveland, 2004). Due to the sectoral changes over time, the energy intensity levels of agriculture vary greatly from one country to another depending on the level of development of the country (Saric1 and Sohtaoğlu, 2012, p. 9). Therefore, the amount of energy used per output is expected to increase in the early stages of development, while it is expected to decrease throughout the later stages (Panayotou, 1993, p. 3; Mehrara, 2007). The history of economics indicates that the share of the services sector in the national income has increased gradually, which also increases the energy consumption of the sector; however, its total energy intensity decreases when the rate of increase is lower than the growth rate of the GDP.

\section{Model, data and methodology}

This study examines the relationship between energy consumption (EC) and economic growth (GDP) in 75 net energy-importing countries. For this purpose, annual data were acquired from the World Development Indicators (WDI) database of the World Bank for these countries for the period 1990 to 2012. The aim is to achieve the optimal sample size when determining the economies and periods within the scope of the analysis. Prior to conducting the empirical analysis, we find a natural logarithm of all variables to reduce heteroscedasticity.

The 75 net energy-importing countries are divided into two main groups based on their level of dependence on energy import and into four subgroups based on their income levels. The first group formed based on the level of dependence on energy import is classified into two subgroups in terms of the import dependence being greater or lesser than 50 per cent according to the data obtained from WDI 2012. The second group is classified into four subgroups based on the World Bank's classification of countries by income group:

- low-income economies;

- lower-middle-income economies;

- upper-middle-income economies; and

- high-income economies.

Table I shows the countries and groups examined in this study.

The model used to test the effect of energy consumption on the economic growth of net energy-importing countries is as follows:

$$
L n G D P_{i t}=\beta_{0}+\beta_{1} L n E C_{i t}+\varepsilon_{i t}
$$

where, $L n E C_{i t}$ is the logarithm of energy consumption ( $\mathrm{kg}$ of oil equivalent per capita) and $L n G D P_{i t}$ is the logarithm of the real GDP per capita (constant 2005 US\$). $\varepsilon_{\text {it }}$ indicates the error term. $i$ represents the units within the scope of the cross-section $(i=1,[\ldots], \mathrm{n})$, and $t$ indicates the dimension of the time series for each unit $(t=1,[\ldots], \mathrm{T})$.

To find a significant relationship between the variables used in the econometric models, the series should be stationary (i.e. it should not have a unit root). Therefore, before performing a panel analysis, it is necessary to perform unit root tests to determine whether the series of the models are stationary and, if they are so, to what extent they are stationary. Different panel unit root tests have been developed to test whether the panel data are stationary over time.

The first problem encountered in the unit root testing of panel data is to specify whether the cross-sections of the panel are independent from each other. The unit roots tests 


\section{JEFAS 22,42}

\section{4}

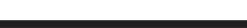

\section{Energy imports, net $\quad<50 \%$}

(\% of energy use)

$>50 \%$

Income groups

Upper-middle-

income economies

\section{Table I.}

Country

classifications for net

energy-importing

economies

High-income

\author{
Albania, Argentina, Bangladesh, Benin, Botswana, \\ Brazil, Bulgaria, China, Costa Rica, Czech Rep., El \\ Salvador, Ethiopia, Finland, France, Ghana, Guatemala, \\ Iceland, India, Kenya, Macedonia, Nepal, \\ The Netherlands, New Zealand, Nicaragua, Pakistan, \\ The Philippines, Poland, Romania, Senegal, Sri Lanka, \\ Sweden, Tajikistan, Tanzania, Thailand, Togo, Tunisia, \\ Ukraine, UK, USA, Zambia \\ Armenia, Austria, Belarus, Belgium, Chile, Cuba, \\ Cyprus, Georgia, Germany, Greece, Honduras, Hong \\ Kong, Hungary, Ireland, Israel, Italy, Jamaica, Japan, \\ Jordan, Korea Rep., Kyrgyz Rep., Lebanon, \\ Luxembourg, Malta, Mauritius, Moldova, Morocco, \\ Namibia, Panama, Portugal, Singapore, Spain, \\ Switzerland, Turkey, Uruguay \\ Benin, Ethiopia, Nepal, Tanzania, Togo \\ Armenia, Bangladesh, El Salvador, Georgia, Ghana, \\ Guatemala, Honduras, India, Kenya, Kyrgyz Rep., \\ Moldova, Morocco, Nicaragua, Pakistan, The \\ Philippines, Senegal, Sri Lanka, Tajikistan, Ukraine, \\ Zambia \\ Albania, Belarus, Botswana, Brazil, Bulgaria, China, \\ Costa Rica, Cuba, Jamaica, Jordan, Lebanon, Macedonia, \\ Mauritius, Namibia, Panama, Romania, Thailand, \\ Tunisia, Turkey \\ Argentina, Austria, Belgium, Chile, Cyprus, Czech Rep., \\ Finland, France, Germany, Greece, Hong Kong, \\ Hungary, Iceland, Ireland, Israel, Italy, Japan, Korea \\ Rep., Luxembourg, Malta, The Netherlands, New \\ Zealand, Poland, Portugal, Singapore, Spain, Sweden, \\ Switzerland, UK, USA, Uruguay
}

developed for the cases where there is no correlation between the units are called firstgeneration tests, while the tests used in cases where there is a correlation between the units are called second-generation tests. First-generation tests are based on the assumption that cross-sections are independent and all cross-sections are equally affected from the impact of the shocks to any of the panel units. However, given the relationships of today's international economies, it is more realistic to assume that the cross-section units are affected differently from a shock to one of the units. In an effort to fill this gap, secondgeneration unit root tests were developed by taking into account the cross-section dependence. The key feature of the second-generation tests is their assumption that there is a correlation between the series of the units. Therefore, the variables analyzed in this study are tested using the cross-sectionally augmented Dickey-Fuller (CADF) unit root test developed by Pesaran (2007) for the panel data.

To decide on which generation root test should be used for testing, first it should be examined whether there is cross-section dependence. The results are affected considerably depending on whether the cross-section dependence between the series is taken into account (Breusch and Pagan, 1980; Pesaran, 2004). If the presence of cross-section dependence in the panel data set is rejected, first-generation unit root tests can be used. However, if there is cross-section dependence in the panel data, then the use of second-generation unit root tests will ensure making more consistent, effective and powerful estimations. In this study, the 
presence of cross-section dependence is examined using the Breusch and Pagan (1980), Pesaran (2004) scaled LM, Pesaran (2004) CD and the Baltagi et al. (2012) bias-corrected scaled LM tests. The tests show that there is cross-section dependence in the series. This means that there is cross-section dependence between the countries in the panel data. Therefore, in the following sections of the study, we will use panel unit root and panel cointegration tests, both of which take account of the cross-section dependence.

Following the tests to check stationarity, the presence of a long-term relationship between the variables will be determined by using cointegration analyses. While forming a hypothesis for the panel cointegration tests, the stationarity level of the variables changes the type of the test to be used. The series analyzed in this study have both heterogeneity and cross-section dependence. Therefore, the error-correction-based panel cointegration test developed by Westerlund (2007), which takes account of cross-section dependence, will be used in this study to test for cointegration between the panel data variables. Westerlund (2007) proposes four different panel cointegration statistics to test the presence of cointegration. Two of these statistics are called group mean statistics (Ga, Gt), while the other two are called panel statistics ( $\mathrm{Pa}, \mathrm{Pt})$.

If a long-term relationship is found between the variables as a result of the panel cointegration tests, it is required to estimate the long-term coefficients for all country groups. In this stage, the coefficients in the cointegrating vector are analyzed by using the dynamic ordinary least squares (DOLS) estimator proposed by Stock and Watson (1993) and the fully modified ordinary least squares (FMOLS) estimator developed by Phillips and Hansen (1990).

In addition to the long-run parameters, estimation of short-run parameters also gives some valuable information. The pooled-mean group estimation (PMGE) proposed by Pesaran et al. (1999) and the mean group estimation (MGE) error correction model proposed by Pesaran and Smith (1995) estimate both the long-term and short-run parameters. In the final stage of the study, PMGE and MGE methods will be used to estimate the short-term and long-term relationship between the variables for each unit. MGE estimates the long-run parameters by using the means of the long-run parameters of the autoregressive distributed lag (ARDL) models for the estimation of the individual units. Therefore, it allows the long-run parameters to change for the units. On the other hand, PMGE holds the long-run parameter constant and allows the short-run parameters, and even the variance, to change for the units.

\section{Empirical results}

\subsection{Panel unit root analysis}

To find econometrically significant relationships between the variables, the series must be stationary. Therefore, the series used in the model must first be tested for stationarity by using unit root tests. In this study, it is necessary to first determine the presence of crosssection dependence to determine which generation root test should be applied. This is important when choosing the unit root and cointegration tests to be performed. Crosssection independence is an important issue for today's markets, as they are becoming increasingly more integrated (Herzer, 2013) as a result of various common factors, such as countries, global financial crises and fluctuating oil prices, all of which can be affected in such an environment (Cavalcanti et al., 2011). Accordingly, the presence of cross-section dependence is examined using the Breusch and Pagan (1980), the Pesaran (2004) scaled LM, Pesaran (2004) CD and the Baltagi et al. (2012) bias-corrected scaled LM tests. These tests examine whether the cross-section units are dependent on each other and whether they are equally affected by a shock to the series. Table II presents the results of the cross-section dependence tests performed on the series. 


\section{JEFAS 22,42}

Table II.

Cross-section dependence test results

\begin{tabular}{|c|c|c|c|c|c|c|c|}
\hline & In all & Energy in & hports, net & $\begin{array}{l}\text { Low-income } \\
\text { economies }\end{array}$ & $\begin{array}{l}\text { Country in } \\
\text { Lower-middle- } \\
\text { income } \\
\text { economies }\end{array}$ & $\begin{array}{l}\text { come groups } \\
\text { Upper-middle- } \\
\text { income } \\
\text { economies }\end{array}$ & $\begin{array}{l}\text { High-income } \\
\text { economies }\end{array}$ \\
\hline \multicolumn{8}{|c|}{$\begin{array}{l}\text { CD tests for } L n G D P_{i t} \\
\text { Breusch and } \\
\text { Pagan (1980) }\end{array}$} \\
\hline $\begin{array}{l}\text { LM test } \\
\text { Pesaran } \\
\text { (2004) scaled }\end{array}$ & 21,199.37* & $1,278.06^{*}$ & $8,519.20 *$ & $113.06^{*}$ & $2,498.75^{*}$ & $3,051.69 *$ & 8,613.18* \\
\hline $\begin{array}{l}\text { LM test } \\
\text { Baltagi et al. }\end{array}$ & $246.30^{*}$ & $302.82^{*}$ & $228.69^{*}$ & $21.92^{*}$ & $117.41^{*}$ & $154.74^{*}$ & $266.17^{*}$ \\
\hline $\begin{array}{l}\text { test } \\
\text { Pesaran }\end{array}$ & $244.60^{*}$ & $301.91^{*}$ & $227.90^{*}$ & $21.81^{*}$ & $116.95^{*}$ & $154.31 *$ & $265.46^{*}$ \\
\hline $\begin{array}{l}(2004) \mathrm{CD} \\
\text { test }\end{array}$ & $39.87 *$ & $106.00^{*}$ & $86.21^{*}$ & $8.16^{*}$ & $45.72 *$ & $54.52^{*}$ & $91.78^{*}$ \\
\hline \multicolumn{8}{|c|}{$\begin{array}{l}\text { CD tests for } L n E C_{i t} \\
\text { Breusch and } \\
\text { Pagan (1980) }\end{array}$} \\
\hline $\begin{array}{l}\text { LM test } \\
\text { Pesaran } \\
\text { (2004) scaled }\end{array}$ & $42,685.89 *$ & 6,715.38* & $4,300.55^{*}$ & $110.29 *$ & $1,955.83^{*}$ & $1,494.12^{*}$ & $2,675.46^{*}$ \\
\hline $\begin{array}{l}\text { LM test } \\
\text { Baltagi et al. }\end{array}$ & $534.72^{*}$ & $149.26^{*}$ & $106.40^{*}$ & $21.30^{*}$ & $89.55^{*}$ & $70.51 *$ & $71.46^{*}$ \\
\hline $\begin{array}{l}\text { test } \\
\text { Pesaran } \\
\text { (2004) CD }\end{array}$ & $533.01 *$ & $148.35^{*}$ & $105.60^{*}$ & $21.19 *$ & $89.10^{*}$ & $70.08^{*}$ & $70.76^{*}$ \\
\hline test & $193.41^{*}$ & $24.66^{*}$ & $14.85^{*}$ & $10.18^{*}$ & $5.06^{*}$ & $16.24 *$ & $23.72^{*}$ \\
\hline
\end{tabular}

The results summarized in Table II indicate that there is cross-section dependence in the panel data used to estimate the model at the 1 per cent significance level for all related sub-categories as well as for the whole data set. This means that any shock to one of the countries affects the other countries. Therefore, while developing energy policies, these countries should take into account the policies adopted by the other countries in the panel, as well as the shocks that affect their energy consumption. For this reason, the stationarity of the series is tested using the CADF test developed by Pesaran (2007), which is one of the second-generation unit root tests that takes cross-section dependence into consideration. This method uses the ADF regression augmented by the lagged cross-section means. The first differences of this regression eliminate the inter-unit correlation (Tatoğlu, 2012). Table III presents the results of the Pesaran (2007) $\mathrm{CADF}$ unit root test performed on the variables in the model.

As shown in Table III, the results of the Pesaran (2007) CADF panel unit root test performed on the economic growth and energy consumption variables indicate that the series are not stationary at the 5 per cent significance level, which means that they have a unit root. Therefore, we take the first difference of each series, thus getting a stationary series. According to these results, we can say that the variables are integrated at the same level and it is possible to examine a relationship in the long term, which can be done through cointegration tests. 


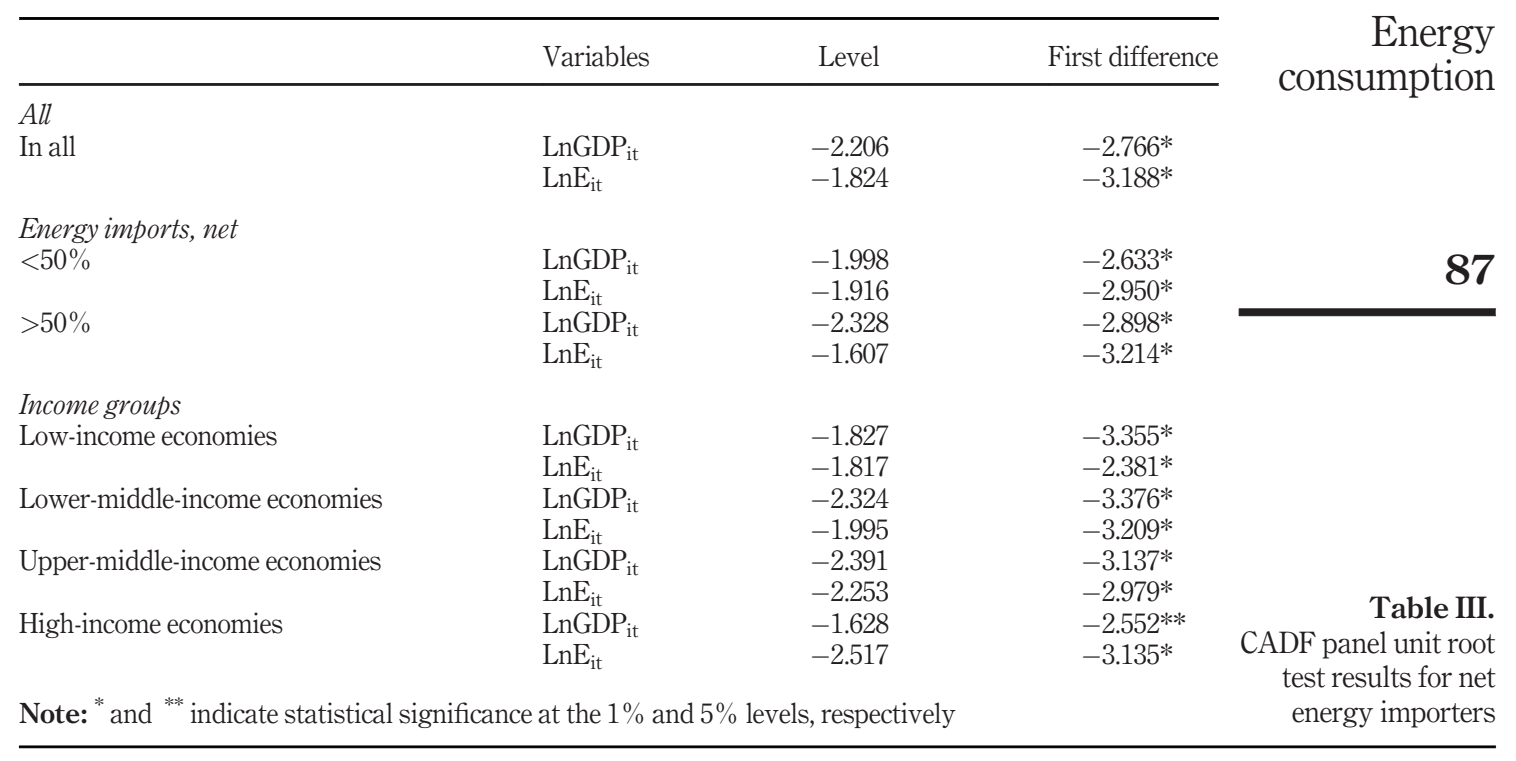

\subsection{Panel data cointegration analysis}

In this study, the presence of a long-term relationship between economic growth and energy consumption is tested using cointegration tests. For this reason, the panel cointegration test developed by Westerlund (2007), which takes into account cross-section dependence, is used to analyze the long-term relationship between variables. Westerlund (2007) proposes comparing the test statistics calculated for cross-section dependence with the bootstrap critical values recommended by Chang (2004) and Westerlund (2007). Table IV presents the results of the panel cointegration analysis.

According to the results of the Westerlund panel cointegration test presented in Table IV, HO, which states that there is no cointegration between the cross-section units in the panel with respect to either the country groups or the relevant sub-categories, is rejected

\begin{tabular}{llccc}
\hline & \multicolumn{2}{c}{ Group-mean tests } & \multicolumn{2}{c}{ Panel tests } \\
& Gt & Ga & Pt & Pa \\
\hline All & & & & \\
In all & $-4.886^{*}$ & $-9.468^{*}$ & $-29.295^{*}$ & $-17.092^{*}$ \\
Energy imports, net & & & & \\
$<50 \%$ & $-4.753^{*}$ & $-10.184^{*}$ & $-23.366^{*}$ & $-16.657^{*}$ \\
$>50 \%$ & $-5.038^{*}$ & $-8.651^{* *}$ & $-18.703^{*}$ & $-17.528^{*}$ \\
Income groups & & & & \\
Low-income economies & $-5.500^{*}$ & $-12.873^{* *}$ & $-12.116^{*}$ & $-18.248^{*}$ \\
Lower-middle-income economies & $-5.081^{*}$ & $-9.034^{* * *}$ & $-15.044^{*}$ & $-19.460^{*}$ \\
Upper-middle-income economies & $-5.945^{*}$ & $-10.774^{*}$ & $-11.785^{*}$ & $-10.277^{*}$ \\
High-income economies & $-4.012^{*}$ & -8.399 & $-16.782^{*}$ & $-15.155^{*}$
\end{tabular}

Note: ${ }^{*}{ }^{* *}$ and ${ }^{* * * *}$ indicate statistical significance at the $1 \%, 5 \%$ and $10 \%$ levels, respectively

Table IV. Error-correctionbased panel cointegration tests 
JEFAS

22,42

by each of the four test statistics. The results further reveal that there is a statistically significant cointegration relationship in the panel data set. Therefore, according to the results of the cointegration analysis of the net energy-importing countries, we conclude that there is a strong relationship between energy consumption and economic growth over the long term.

\subsection{Short-run and long-run parameter estimates}

If a long-term relationship is found between the variables as a result of the panel cointegration tests, the cointegration coefficients for all country groups and other subcategories must be estimated. In this study, the coefficients in the cointegrating vector are analyzed using the dynamic OLS estimator and the fully modified OLS estimator. Table V presents the coefficients estimated using the DOLS and FMOLS estimators.

Table $\mathrm{V}$ displays the estimation results of a long-term relationship between energy consumption and economic growth. According to the results presented in the table, $t$-statistics for the common long-term coefficients are statistically significant at the 1 per cent level for all country groups and for other sub-categories, except for low-income net energy-importing economies. The results obtained from the DOLS and FMOLS estimation techniques indicate that there is a long-run, positive relationship between energy consumption and economic growth. Thus, a 1 per cent increase in energy consumption in the long term will increase economic growth by 0.24 to 0.48 per cent based on the DOLS estimator and by 0.06 to 0.60 per cent based on the FMOLS estimator. Both the DOLS and FMOLS estimates reveal that the level of energy use is an influential factor on economic growth in the net energy-importing country groups.

Panel DOLS and FMOLS estimation methods are used to estimate only the long-run parameters. However, in addition to the long-run parameters, estimation of short-run parameters also gives some valuable information. Therefore, we will use PMGE and MGE as a panel error correction model to examine both the long-term and short-run relationship between energy consumption and economic growth. Table VI shows the results of the analysis.

According to the PMGE and MGE results, the error correction parameter is negative and significant for all of the net energy-importing countries and subgroups. The error correction parameter represents the adjustment speed of the short-run deviations caused by the nonstationarity of the series to equilibrium in the next period. According to the PMGE method,

\begin{tabular}{lcccc}
\hline & \multicolumn{2}{c}{ DOLS } & \multicolumn{2}{c}{ FMOLS } \\
& $\beta$ & $t$-statistics & $\beta$ & $t$-statistics \\
\hline All & & & & \\
In all & 0.37 & $12.44^{*}$ & 0.43 & $9.21^{*}$ \\
Energy imports, net & & & & \\
$<50 \%$ & 0.43 & $13.84^{*}$ & 0.53 & $13.21^{*}$ \\
$>50 \%$ & 0.33 & $7.04^{*}$ & 0.40 & $5.21^{*}$ \\
Income groups & & & & \\
Low-income economies & 0.05 & 0.51 & 0.15 & 1.13 \\
Lower-middle-income economies & 0.48 & $10.46^{*}$ & 0.60 & $13.18^{*}$ \\
Upper-middle-income economies & 0.37 & $12.30^{*}$ & 0.40 & $10.25^{*}$ \\
High-income economies & 0.24 & $3.65^{*}$ & 0.06 & $0.52^{*}$ \\
Note: ${ }^{*}$ indicate statistical significance at the $1 \%$ level, respectively & & \\
\hline
\end{tabular}

Table V.

The panel cointegration coefficients for net energy importers
Note: * indicate statistical significance at the $1 \%$ level, respectively 


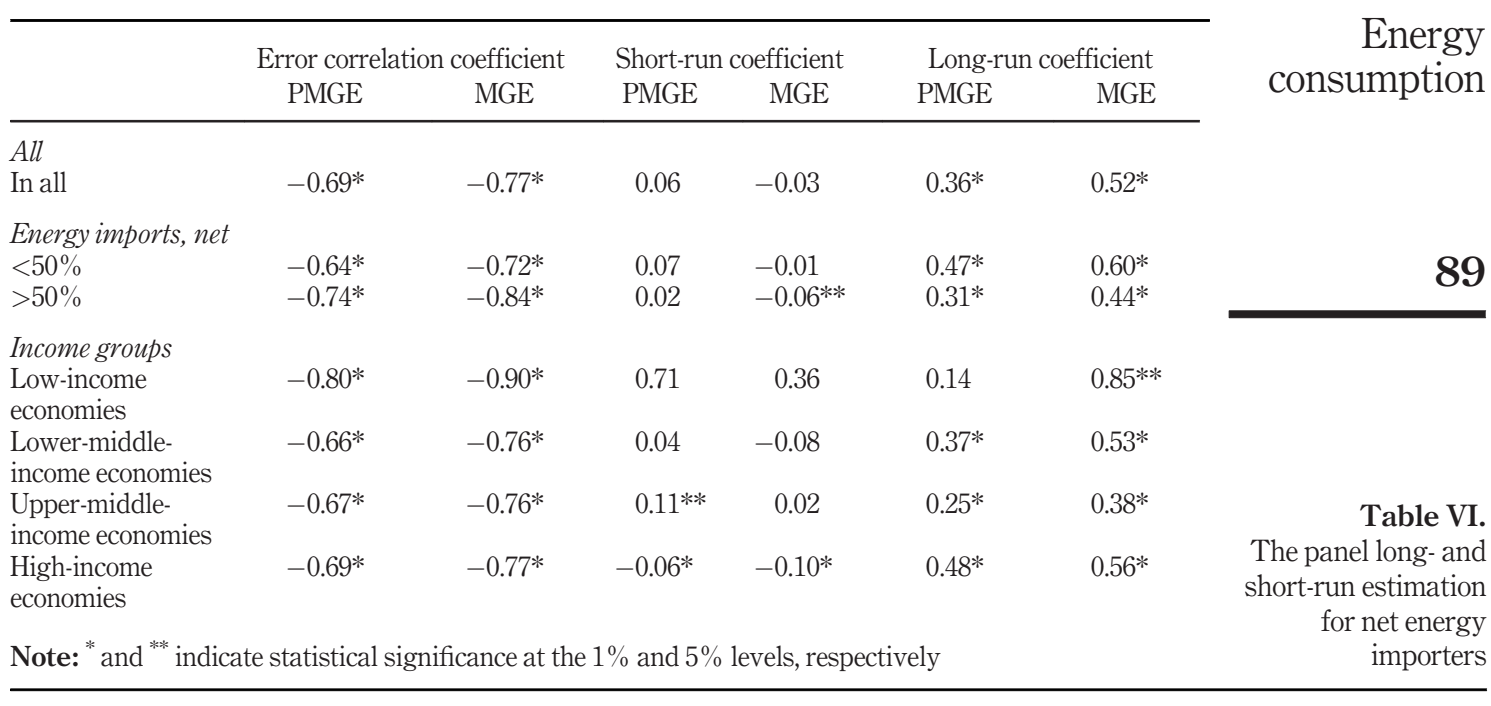

approximately 69 per cent of the disequilibrium in a period can be corrected in the following period, and thus, long-term equilibrium can be attained. This rate was 64 per cent for countries with import dependence less than 50 per cent and 74 per cent for countries with import dependence greater than 50 per cent. Furthermore, with respect to the economic subgroups, the rate of disequilibrium was 80 per cent for the low-income economies, 66 per cent for the lower-middle-income economies, 66 per cent for the upper-middle-income economies and 69 per cent for the high-income economies. Additionally, the long-term parameters of the energy consumption variable in the model were significant and positive for all groups, except for the low-income economies, a result that is consistent with a priori expectations. In other words, a 1 per cent increase in energy consumption increases the GDP per capita by 0.36 per cent for all net energy-importing countries, by 0.47 per cent for countries with import dependence less than 50 per cent and by 0.31 per cent for those countries with import dependence greater than 50 per cent. If we categorize the net energy importers by income levels, this increase is 0.14 per cent for the low-income economies, 0.37 per cent for the lower-middle-income economies, 0.25 per cent for the upper-middle-income economies and 0.48 per cent for the high-income economies. The short-run parameter of energy consumption is statistically insignificant, except for the upper-middle-income economies and high-income economies.

According to the MGE results shown in Table VI, about 77 per cent of the disequilibrium in a period can be corrected in the following period and the long-term equilibrium can be reached. This rate is found to be 72 per cent for the countries with import dependence less than 50 per cent and 84 per cent for those with import dependence greater than 50 per cent and to be 90 per cent for the low-income economies, 76 per cent for the lower-middle-income economies, 76 per cent for the upper-middle-income economies and 72 per cent for the highincome economies. Besides, the long-term parameters of the energy consumption variable in the model were found to be significant and positive for all groups, which is a result consistent with a priori expectations. The short-run parameter was found to be statistically significant only in the group formed based on the dependence level of the countries. Only the 
JEFAS

22,42

90

short-term parameters of the country group with high import dependence and the country group with high income levels are statistically significant.

In this stage, PMGE and MGE methods are used to estimate both the short-term and long-term relationship between energy consumption and economic growth variables for each unit. Table VII shows the PMGE and MGE estimation results for the net energyimporting low-income countries.

As the PMGE results for the low-income economies show, only one long-term parameter is estimated (0.14); however, the error correction parameter and the short-run coefficient are calculated separately for each unit. According to the results of the analysis, the error correction parameter calculated for each net energy-importing low-income economy is statistically significant and negative. This indicates the presence of a long-term relationship between the variables. In addition, the long-run and short-run parameters of energy consumption, except for Ethiopia, are found to be statistically insignificant. The error correction parameters of all countries, except for Tanzania, are considerably high. Therefore, the adjustment speed of short-run deviations to long-run equilibrium is extremely high in these countries.

As shown in Table VII, contrary to the PMGE method, MGE estimates separate longterm parameters for each unit. Besides, the error correction parameter and the short-run coefficient change depending on the units. According to the MGE results obtained for each unit of the low-income economies, the error correction parameter is statistically significant and negative. This indicates the presence of a long-term relationship between the variables for the country group analyzed. However, the long-run parameters, except for Nepal and Tanzania, and the short-run coefficients were found to be insignificant. Table VIII shows the PMGE and MGE estimation results for the lower-middle-income countries dependent on external energy resources.

As the PMGE results for the lower-middle-income economies show, only one long-term parameter is estimated (0.37); however, the error correction parameter and the short-run coefficient are calculated separately for each unit. According to the results of the analysis, the error correction parameter calculated for each net energy-importing lower-middleincome economy is statistically significant, except for Bangladesh, and negative. This indicates the presence of a long-term relationship between the variables. In addition, the long-run coefficient of energy consumption is found to be statistically significant and positive for all countries. However, the short-run parameters are found to be statistically insignificant for the countries, except for Armenia, Guatemala, The Philippines, Senegal, Tajikistan and Ukraine.

According to the MGE results shown in Table VIII and obtained for each unit of the lower-middle-income economies, the error correction parameter is statistically significant and negative for all countries, except for Bangladesh, Georgia and Senegal. This indicates

Table VII.

Individual long- and short-run estimation for net energy importers of lowincome

\begin{tabular}{|c|c|c|c|c|c|c|}
\hline \multirow[b]{2}{*}{ Country } & \multicolumn{2}{|c|}{ Error correlation coefficient } & \multicolumn{2}{|c|}{ Short-run coefficient } & \multicolumn{2}{|c|}{ Long-run coefficient } \\
\hline & PMGE & MGE & PMGE & MGE & PMGE & MGE \\
\hline Benin & $-0.79 *$ & $-0.98^{*}$ & -0.07 & -0.03 & 0.14 & 0.01 \\
\hline Ethiopia & $-0.66^{*}$ & $-0.77^{*}$ & $3.85^{*}$ & 2.87 & 0.14 & 2.08 \\
\hline Nepal & $-1.24^{*}$ & $-1.34^{*}$ & -0.11 & -0.40 & 0.14 & $0.42^{* * * *}$ \\
\hline Tanzania & $-0.35^{*}$ & $-0.49 *$ & -0.04 & -0.30 & 0.14 & $1.06^{* * *}$ \\
\hline Togo & $-0.95^{*}$ & $-0.95^{*}$ & -0.06 & -0.32 & 0.14 & 0.68 \\
\hline
\end{tabular}




\begin{tabular}{|c|c|c|c|c|c|c|c|}
\hline \multirow[b]{2}{*}{ Country } & \multicolumn{2}{|c|}{ Error correlation coefficient } & \multicolumn{2}{|c|}{ Short-run coefficient } & \multicolumn{2}{|c|}{ Long-run coefficient } & \multirow{2}{*}{$\begin{array}{r}\text { Energy } \\
\text { consumption }\end{array}$} \\
\hline & PMGE & MGE & PMGE & MGE & PMGE & MGE & \\
\hline Armenia & $-1.01^{*}$ & $-0.92 *$ & $0.22 *$ & $0.28 * *$ & $0.37 *$ & $0.28^{* *}$ & \\
\hline Bangladesh & -0.16 & -0.15 & 0.06 & 0.11 & $0.37 *$ & -0.29 & \\
\hline El Salvador & $-0.71^{*}$ & $-0.69^{*}$ & -0.03 & -0.11 & $0.37^{*}$ & $0.61^{*}$ & \\
\hline Georgia & $-0.31^{* * * *}$ & -0.27 & -0.10 & -0.04 & $0.37^{*}$ & -0.08 & \\
\hline Ghana & $-0.43 * *$ & $-0.45^{* *}$ & -0.18 & -0.12 & $0.37^{*}$ & 0.13 & 91 \\
\hline Guatemala & $-0.48^{*}$ & $-0.81 *$ & $-0.11^{* *}$ & -0.03 & $0.37^{*}$ & 0.02 & \\
\hline Honduras & $-1.12^{*}$ & $-1.12^{*}$ & -0.11 & -0.05 & $0.37^{*}$ & $0.28^{*}$ & \\
\hline India & $-0.90 *$ & $-0.99 *$ & -0.07 & -0.36 & $0.37^{*}$ & $0.88^{*}$ & \\
\hline Kenya & $-0.72^{*}$ & $-0.79 *$ & -0.30 & $-0.88^{*}$ & $0.37 *$ & $1.73^{*}$ & \\
\hline Kyrgyz Rep. & $-0.58^{*}$ & $-0.67 *$ & -0.01 & -0.09 & $0.37 *$ & $0.51^{*}$ & \\
\hline Moldova & $-0.77^{*}$ & $-1.33^{*}$ & 0.50 & -0.51 & $0.37^{*}$ & $1.26^{*}$ & \\
\hline Morocco & $-1.59^{*}$ & $-1.58^{*}$ & -0.01 & 0.26 & $0.37 *$ & 0.02 & \\
\hline Nicaragua & $-0.67^{*}$ & $-0.65^{*}$ & 0.18 & 0.35 & $0.37^{*}$ & -0.05 & \\
\hline Pakistan & $-0.66^{*}$ & $-0.72^{*}$ & 0.21 & 0.12 & $0.37 *$ & $0.55^{* *}$ & \\
\hline The Philippines & $-0.46^{*}$ & $-0.53^{*}$ & $0.17 * * *$ & $0.32^{* *}$ & $0.37 *$ & -0.26 & \\
\hline Senegal & $-0.72^{*}$ & -0.01 & $-0.14 * * *$ & $-1.05^{*}$ & $0.37^{*}$ & 0.03 & \\
\hline Sri Lanka & $-0.51^{* *}$ & $-0.45^{* * * *}$ & 0.06 & 0.04 & $0.37^{*}$ & 0.53 & Individual long-and \\
\hline Tajikistan & $-0.30 * *$ & $-0.57^{*}$ & $0.39 * * *$ & 0.04 & $0.37^{*}$ & $1.15^{*}$ & \\
\hline Ukraine & $-0.27^{* * * * *}$ & $-0.69 *$ & $0.36^{* * *}$ & $-0.43^{*}$ & $0.37 *$ & $2.00^{*}$ & \\
\hline Zambia & $-0.82^{*}$ & $-0.89 *$ & -0.17 & -0.59 & $0.37^{*}$ & 1.25 & rgy \\
\hline Note: ${ }^{*},{ }^{* *}$ an & at & nif & $1 \%$ & & & & middle-income \\
\hline
\end{tabular}

the presence of a long-term relationship between the variables for the country group analyzed. The effect of energy consumption on economic growth is strong in El Salvador, India, Kenya, Moldova, Tajikistan and Ukraine, as the long-run coefficients were estimated to be high in these countries. On the other hand, this effect is weak in Armenia, Honduras, Kyrgyz Rep. and Pakistan, as they were found to have low long-run coefficients. The longrun coefficients were found to be statistically insignificant for the other countries. Besides, the short-run coefficients are also insignificant for the countries, except for Armenia, Kenya, The Philippines, Senegal and Ukraine. Table IX shows the PMGE and MGE results for the upper-middle-income economies dependent on external energy resources.

According to the PMGE results obtained for each net energy-importing upper-middleincome economy, the error correction parameter is statistically significant, except for Belarus, and negative. This indicates the presence of a long-term relationship between the variables. Besides, the long-run coefficient of energy consumption (0.25) was found to be significant and positive for all countries. However, the short-run parameters were found to be statistically insignificant for the countries, except for Belarus, Brazil, Lebanon, Romania, Thailand and Turkey. This indicates the presence of a short-term relationship between energy consumption and economic growth only for these five countries.

According to the MGE results shown in Table IX and obtained for each unit of the lowermiddle-income economies, the error correction parameter is statistically significant and negative for all countries. This indicates the presence of a long-term relationship between the variables for the country group analyzed. However, only the long-run parameters of Albania, Belarus, Brazil, Bulgaria, Jamaica, Jordan, Lebanon, Macedonia, Romania and Turkey are statistically significant. Moreover, the short-run coefficients were found to be statistically insignificant for the countries, except for Belarus, Brazil, Lebanon, Romania and 


\begin{tabular}{|c|c|c|c|c|c|c|c|}
\hline \multirow{2}{*}{$\begin{array}{l}\text { JEFAS } \\
22,42\end{array}$} & \multirow[b]{2}{*}{ Country } & \multicolumn{2}{|c|}{ Error correlation coefficient } & \multicolumn{2}{|c|}{ Short-run coefficient } & \multicolumn{2}{|c|}{ Long-run coefficient } \\
\hline & & PMGE & MGE & PMGE & MGE & PMGE & MGE \\
\hline \multirow{5}{*}{92} & Albania & $-0.89 *$ & $-0.92^{*}$ & 0.10 & 0.08 & $0.25^{*}$ & $0.28 * *$ \\
\hline & Belarus & -0.17 & $-0.59 *$ & $0.51^{*}$ & 0.01 & $0.25^{*}$ & $1.06^{*}$ \\
\hline & Botswana & $-1.14^{*}$ & $-1.15^{*}$ & -0.01 & 0.04 & $0.25^{*}$ & 0.14 \\
\hline & Brazil & $-0.82^{*}$ & $-1.08^{*}$ & $0.20^{* * * *}$ & -0.17 & $0.25^{*}$ & $0.75^{*}$ \\
\hline & Bulgaria & $-0.52^{*}$ & $-0.56^{*}$ & 0.06 & -0.06 & $0.25^{*}$ & $0.83^{*}$ \\
\hline \multirow{15}{*}{$\begin{array}{l}\text { Table IX. } \\
\text { Individual long-and } \\
\text { short-run estimation } \\
\text { for net energy } \\
\text { importers of upper- } \\
\text { middle-income }\end{array}$} & China & $-0.33 * *$ & $-0.35 * * *$ & 0.10 & 0.10 & $0.25^{*}$ & 0.18 \\
\hline & Costa Rica & $-0.76^{*}$ & $-0.78^{*}$ & -0.01 & 0.01 & $0.25^{*}$ & 0.18 \\
\hline & Cuba & $-0.31 * *$ & $-0.36 * *$ & 0.14 & 0.08 & $0.25^{*}$ & 0.50 \\
\hline & Jamaica & $-0.79 *$ & $-0.80^{*}$ & -0.05 & -0.03 & $0.25^{*}$ & $0.20 * *$ \\
\hline & Jordan & $-1.23^{*}$ & $-1.23^{*}$ & -0.08 & -0.13 & $0.25^{*}$ & $0.33^{* *}$ \\
\hline & Lebanon & $-0.98^{*}$ & $-0.97^{*}$ & $-0.10^{* *}$ & -0.06 & $0.25^{*}$ & $0.16^{* * *}$ \\
\hline & Macedonia & $-0.33 * *$ & $-0.37 * *$ & -0.01 & 0.03 & $0.25^{*}$ & -0.03 \\
\hline & Mauritius & $-1.25^{*}$ & $-1.27 *$ & -0.09 & -0.05 & $0.25^{*}$ & 0.17 \\
\hline & Namibia & $-0.72 * *$ & $-0.84^{*}$ & -0.12 & 0.08 & $0.25^{*}$ & -0.27 \\
\hline & Panama & $-0.34 * *$ & $-0.34 * * *$ & -0.07 & -0.06 & $0.25^{*}$ & 0.19 \\
\hline & Romania & $-0.45^{*}$ & $-0.73^{*}$ & $0.29 * *$ & 0.01 & $0.25^{*}$ & $0.78^{*}$ \\
\hline & Thailand & $-0.34 *$ & $-0.42 * *$ & $0.58^{*}$ & $0.49 * *$ & $0.25^{*}$ & 0.50 \\
\hline & Tunisia & $-0.74^{*}$ & $-0.77 *$ & 0.07 & $0.03 *$ & $0.25^{*}$ & 0.34 \\
\hline & Turkey & $-0.55^{*}$ & $-0.96^{*}$ & $0.61^{*}$ & 0.01 & $0.25^{*}$ & $0.98^{*}$ \\
\hline & \multicolumn{7}{|c|}{ Note: ${ }^{*}, *$ and ${ }^{* * *}$ indicate statistical significance at the $1 \%, 5 \%$ and $10 \%$ levels, respectively } \\
\hline
\end{tabular}

Turkey. Table $\mathrm{X}$ shows the PMGE and MGE results for the high-income economies dependent on external energy resources.

According to the PMGE results obtained for each net energy-importing high-income economy, the error correction parameter is statistically significant, except for Greece, and negative. This indicates the presence of a long-term relationship between the variables. Furthermore, the long-run coefficient of energy consumption (0.48) was found to be significant and positive for all countries. However, the short-run parameters were found to be statistically insignificant for all countries, except Austria, Belgium, Cyprus, Finland, France, Hong Kong, Hungary, Korea Rep., Malta, Poland, Switzerland and Uruguay. This indicates the presence of a short-term relationship between energy consumption and economic growth only for these ten countries. The error correction parameter was found to be considerably high in Germany, Hungary, Italy and Portugal. Thus, it is found that the adjustment speed of short-run deviations to long-run equilibrium is extremely high in these countries.

According to the MGE results shown in Table $\mathrm{X}$ and obtained for each unit of the lower-middle-income economies, the error correction parameter is statistically significant and negative for all countries. This indicates the presence of a long-term relationship between the variables for the country group analyzed. However, only the long-run parameters of Argentina, Belgium, Chile, Czech Rep., Finland, Greece, Hungary, Ireland, Italy, Japan, Korea Rep., Portugal, Spain, Sweden, the UK, the USA and Uruguay are statistically significant. The five countries in which energy consumption has the highest increasing effect on economic growth are Argentina, Ireland, Finland, the UK and the USA, respectively. The short-run coefficients were found to be statistically insignificant for the countries, except for Finland, Hungary, Ireland and the UK. 


\begin{tabular}{|c|c|c|c|c|c|c|c|}
\hline \multirow[b]{2}{*}{ Country } & \multicolumn{2}{|c|}{ Error correlation coefficient } & \multicolumn{2}{|c|}{ Short-run coefficient } & \multicolumn{2}{|c|}{ Long-run coefficient } & \multirow{2}{*}{$\begin{array}{l}\text { Energy } \\
\text { consumption }\end{array}$} \\
\hline & PMGE & MGE & PMGE & MGE & PMGE & MGE & \\
\hline Argentina & $-0.67 *$ & $-0.92 *$ & 0.22 & -0.49 & $0.48^{*}$ & $1.70^{*}$ & \\
\hline Austria & $-0.76^{*}$ & $-0.78^{*}$ & $-0.14 * * *$ & -0.13 & $0.48^{*}$ & 0.43 & \\
\hline Belgium & $-0.86^{*}$ & $-0.91 *$ & $-0.16^{* * *}$ & -0.12 & $0.48 *$ & $0.38 * *$ & \\
\hline Chile & $-0.76^{*}$ & $-0.76^{*}$ & 0.01 & 0.01 & $0.48^{*}$ & $0.39 * *$ & \\
\hline Cyprus & $-0.78^{*}$ & $-0.87^{*}$ & $-0.16^{* *}$ & -0.10 & $0.48^{*}$ & 0.29 & 93 \\
\hline Czech Rep. & $-0.73^{*}$ & $-0.74 *$ & 0.05 & 0.05 & $0.48 *$ & 0.50 *** & \\
\hline Finland & $-0.73^{*}$ & $-0.63^{*}$ & $-0.14 * * *$ & $-0.30 *$ & $0.48^{*}$ & $1.08^{*}$ & \\
\hline France & $-0.78^{*}$ & $-0.83^{*}$ & $-0.16^{* *}$ & -0.08 & $0.48^{*}$ & 0.25 & \\
\hline Germany & $-0.90 *$ & $-0.85^{*}$ & -0.09 & -0.17 & $0.48^{*}$ & 0.71 & \\
\hline Greece & -0.21 & $-0.52 *$ & 0.11 & -0.38 & $0.48^{*}$ & $1.79 *$ & \\
\hline Hong Kong & $-0.34 *$ & $-0.72^{*}$ & $-0.23 *$ & -0.10 & $0.48^{*}$ & -0.04 & \\
\hline Hungary & $-0.98^{*}$ & $-0.99 *$ & $-0.20 * *$ & $-0.37 * *$ & $0.48^{*}$ & $0.85^{*}$ & \\
\hline Iceland & $-0.61^{*}$ & $-0.64^{*}$ & -0.04 & 0.02 & $0.48^{*}$ & 0.23 & \\
\hline Ireland & $-0.42 * *$ & $-0.69 *$ & -0.12 & $-0.45^{* *}$ & $0.48^{*}$ & $1.20^{*}$ & \\
\hline Israel & $-0.84^{*}$ & $-0.85^{*}$ & -0.12 & -0.04 & $0.48^{*}$ & 0.24 & \\
\hline Italy & $-0.97^{*}$ & $-0.97^{*}$ & 0.07 & -0.17 & $0.48^{*}$ & $0.67 *$ & \\
\hline Japan & $-0.83^{*}$ & $-0.79 *$ & 0.03 & 0.02 & $0.48 *$ & $0.56^{*}$ & \\
\hline Korea Rep. & $-0.85^{*}$ & $-0.84^{*}$ & $0.20 * * *$ & 0.23 & $0.48^{*}$ & $0.44^{*}$ & \\
\hline Luxembourg & $-0.66^{*}$ & $-0.75^{*}$ & 0.04 & 0.10 & $0.48^{*}$ & 0.22 & \\
\hline Malta & $-0.53^{*}$ & $-0.92^{*}$ & $-0.17^{*}$ & -0.05 & $0.48^{*}$ & 0.05 & \\
\hline The Netherlands & $-0.50 *$ & $-0.47 *$ & -0.09 & -0.13 & $0.48^{*}$ & 0.69 & \\
\hline New Zealand & $-0.66^{*}$ & $-0.69 *$ & 0.01 & 0.09 & $0.48^{*}$ & 0.12 & \\
\hline Poland & $-0.76^{*}$ & $-0.79^{*}$ & $-0.20 * *$ & -0.12 & $0.48^{*}$ & 0.27 & \\
\hline Portugal & $-0.90 *$ & $-0.91 *$ & -0.12 & -0.10 & $0.48 *$ & $0.45^{*}$ & \\
\hline Singapore & $-0.59 *$ & $-0.98 *$ & -0.07 & -0.01 & $0.48^{*}$ & 0.11 & \\
\hline Spain & $-0.42 * *$ & $-0.41 *$ & 0.12 & 0.07 & $0.48^{*}$ & $0.79 *$ & \\
\hline Sweden & $-0.67 *$ & $-0.62^{*}$ & 0.01 & -0.05 & $0.48^{*}$ & $0.72^{* * *}$ & Table X \\
\hline Switzerland & $-0.63^{*}$ & $-0.68^{*}$ & $-0.16^{* * *}$ & 0.01 & $0.48 *$ & -0.05 & Individual ane \\
\hline UK & $-0.65^{*}$ & $-0.65^{*}$ & -0.11 & $-0.25^{* *}$ & $0.48^{*}$ & $0.94 *$ & sharviual long-and \\
\hline USA & $-0.61 *$ & $-0.77^{*}$ & 0.19 & -0.06 & $0.48^{*}$ & $0.91^{*}$ & short-run estimation \\
\hline Uruguay & $-0.75^{*}$ & $-0.77^{*}$ & $-0.17^{* *}$ & -0.15 & $0.48^{*}$ & $0.41^{*}$ & $\begin{array}{l}\text { for net energy } \\
\text { importers of high- }\end{array}$ \\
\hline : *** and & ta & icanc & $1 \%, 5 \%$ & (1) & ativa & & $\begin{array}{l}\text { income } \\
\text { ind }\end{array}$ \\
\hline
\end{tabular}

\section{Conclusions}

Energy is a key input that is used in all phases of production and an important resource consumed as an output for increasing the welfare level of societies. As a key determinant of economic and social development, energy is not only considered to be a production input, but it is also a strategic commodity that constitutes the basis for international relations and shapes the world economy and politics. As in the past, energy today plays an important role in the production process, and thus, it is one of the key factors that directly or indirectly determines the production structures of the countries and their competitiveness in the national and international markets, as well as their budget balances, current account deficits and economic growth rates. Accordingly, we believe that the findings of this study make a significant contribution to the efforts of policy makers and market participants, as they seek to achieve steady and sustainable growth by means of determining whether energy consumption affects economic growth and, if so, the extent of this effect. 
JEFAS

22,42

In this study, a panel data analysis of 75 net energy-importing countries was performed using data for the period 1990 to 2012 to test the effects of energy consumption on economic growth. In the analysis, the countries were divided into two groups. The first group was formed based on the country's level of dependence on energy imports and was classified into two subgroups, specifically, countries with energy import dependence greater than or less than 50 per cent. The second group was classified into four subgroups based on the World Bank's classification of countries by income group to analyze the effect of energy consumption on economic growth in the net energy-importing countries with different levels of development. The subgroups included low-income economies, lower-middle-income economies, upper-middle-income economies and high-income economies.

As part of the panel data analysis, the presence of cross-section dependence in the panel data was tested. As cross-section dependence was observed in the panels, the stationarity of the series was assessed using the CADF test developed by Pesaran (2007), which is one of the second-generation unit root tests. To test the cointegration relationship between the variables, the panel cointegration test developed by Westerlund (2007), which takes into account cross-section dependence, was used. In addition, the DOLS and FMOLS estimators were used to estimate the long-run coefficients. In the final stage of the study, PMGE and MGE methods were used to estimate the short-term and long-term relationships between the variables for both the panel data and each individual unit.

The findings obtained for both the panel data and for each country indicate that there is a positive and statistically significant relationship between energy consumption and economic growth in the long term. This suggests that the level of energy use is an influential factor that affects economic growth in the net energy-importing country groups, thus supporting the growth hypothesis. No relationships were observed in the countries other than those in the high-income group in the short-run analyses.

The analysis performed based on the energy import dependence of the countries indicates that the effect of energy consumption on economic growth is greater in countries with energy dependence less than 50 per cent compared to countries whose energy dependence exceeds 50 per cent. This finding indicates that the effect of energy consumption on economic growth changes depending on the energy deficit levels of countries. Therefore, we contend that future studies that examine the relationship between energy and growth by using a threshold analysis method will make a significant contribution to the relevant literature.

The analysis performed based on the income levels of the net energy-importing countries reveals that the long-run parameter is statistically insignificant for low-income economies. However, for the other country groups, it was found that energy consumption has a positive and statistically significant effect on economic growth. This effect decreases as the level of development (income) increases, indicating that countries use their energy resources for production more effectively and more efficiently as their level of development increases and that they keep the energy required per unit product low, thus realizing more output with less energy consumption. Among the reasons for this are the low levels of loss and theft in the transmission and distribution of electricity in the developed countries. Other reasons may include sustainable gains with regard to the effective and efficient use of energy in developed countries, the preference of such countries to abandon energy-intensive production activities or transfer such activities to developing countries and focus instead on technology-intensive production fields and the preference to improve the services sector. We expect that these findings will make a valuable contribution to the results of future studies, as they analyze the relationships among the variables by including the energy intensities of the countries. 


\section{References}

Akarca, A.T. and Long, T.V. (1980), "Relationship between energy and GNP: a reexamination", The Journal of Energy and Development, Vol. 5 No. 2, pp. 326-331.

Altinay, G. and Karagol, E. (2004), "Structural break, unit root, and the causality between energy consumption and GDP in Turkey", Energy Economics, Vol. 26 No. 6, pp. 985-994, available at: http://dx.doi.org/10.1016/j.eneco.2004.07.001

Altinay, G. and Karagol, E. (2005), "Electricity consumption and economic growth: evidence from Turkey”, Energy Economics, Vol. 27 No. 6, pp. 849-856, available at: http://dx.doi.org/10.1016/j. eneco.2005.07.002

Apergis, N. and Payne, J.E. (2010), "Energy consumption and growth in South America: evidence from a panel error correction model”, Energy Economics, Vol. 32 No. 6, pp. 1421-1426, available at: http://dx.doi.org/10.1016/j.eneco.2010.04.006

Apostolakis, B.E. (1990), "Energy-capital substitutability/complementarity: the dichotomy", Energy Economics, Vol. 12 No. 1, pp. 48-58, available at: http://dx.doi.org/10.1016/0140-9883(90)90007-3

Asaduzzaman, M. (1995), "Energy savings potentials, issues and constraints", in Catrinus, J.J. (Eds), The Feasibility of Joint Implementation, Kluwer Academic Publishers, pp. 267-284, available at: 10.1007/978-94-015-8559-0_21

Aydın, F.F. (2010), "Energy consumption and economic growth", Erciyes Üniversitesi İIBF Dergisi, Vol. 35, pp. 317-340.

Baltagi, B.H., Feng, Q. and Kao, C. (2012), "A Lagrange multiplier test for cross section dependence in a fixed effects panel data model”, Journal of Econometrics, Vol. 170 No. 1, pp. 164-177, available at: http://dx.doi.org/10.1016/j.jeconom.2012.04.004

Bataille, C., Jaccard, M., Nyboer, J. and Rivers, N. (2006), "Towards general equilibrium in a technologyrich model with empirically estimated behavioral parameters", The Energy Journal, Vol. 27, pp. 93-112.

Berndt, E.R. and Wood, D.O. (1975), "Technology, prices, and the derived demand for energy", The Review of Economics and Statistics, Vol. 57 No. 3, pp. 259-268, available at: 10.2307/1923910

Boyd, G.A. and Pang, J.X. (2000), "Estimating the linkage between energy efficiency and productivity", Energy Policy, Vol. 28 No. 5, pp. 289-296, available at: http://dx.doi.org/10.1016/S0301-4215(00) 00016-1

Breusch, T.S. and Pagan, A.R. (1980), "The Lagrange multiplier test and its applications to model specification in econometrics", The Review of Economic Studies, Vol. 47 No. 1, pp. 239-253.

Cavalcanti, T.V.D.V., Mohaddes, K. and Raissi, M. (2011), "Growth, development and natural resources: new evidence using a heterogeneous panel analysis", The Quarterly Review of Economics and Finance, Vol. 51 No. 4, pp. 305-318, available at: http://dx.doi.org/10.1016/j.qref.2011.07.007

Chang, Y. (2004), "Bootstrap unit root tests in panels with cross-sectional dependency", Journal of Econometrics, Vol. 120 No. 2, pp. 263-293, available at: http://dx.doi.org/10.1016/S0304-4076(03) 00214-8

Cheng, B.S. (1995), “An investigation of cointegration and causality between energy consumption and economic growth", The Journal of Energy and Development, Vol. 21 No. 1, pp. 73-84.

Cleveland, C.J., Kaufmann, R.K. and Stern, D.I. (2000), "Aggregation and the role of energy in the economy”, Ecological Economics, Vol. 32 No. 2, pp. 301-317, available at: http://dx.doi.org/ 10.1016/S0921-8009(99)00113-5

Ebohon, O.J. (1996), "Energy, economic growth and causality in developing countries: a case study of Tanzania and Nigeria", Energy policy, Vol. 24 No. 5, pp. 447-453, available at: http://dx.doi.org/ 10.1016/0301-4215(96)00027-4

EMO (2012), "Enerji verimliliği raporu", TMMOB Elektrik Mühendisleri Odası, EMO Yayınları, Bask1, Ankara, No: GY/2012/3. 
JEFAS 22,42

Frondel, M. and Schmidt, C.M. (2002), “The capital-energy controversy: an artifact of cost shares?”, The Energy Journal, Vol. 23 No. 3, pp. 53-79.

Gibbons, J. (1984), “Capital-energy substitution in the long run”, The Energy Journal, Vol. 5 No. 2, pp. 109-118.

Greening, L.A., Greene, D.L. and Difiglio, C. (2000), "Energy efficiency and consumption-the rebound effect-a survey", Energy Policy, Vol. 28 No. 6, pp. 389-401, available at: http://dx.doi.org/10.1016/ S0301-4215(00)00021-5

Herzer, D. (2013), "Cross-country heterogeneity and the trade-income relationship”, World Development, Vol. 44, pp. 194-211, available at: http://dx.doi.org/10.1016/j.worlddev.2012.09.014

Hondroyiannis, G., Lolos, S. and Papapetrou, E. (2002), "Energy consumption and economic growth: assessing the evidence from Greece”, Energy Economics, Vol. 24 No. 4, pp. 319-336, available at: http://dx.doi.org/10.1016/S0140-9883(02)00006-3

Huang, M., Liao, S. and Jeng, H. (2006), "Substitution between energy and non-energy inputs in Taiwan's manufacturing sector", International Conference on Business and Information 2006, Proceedings of Business and Information, Singapore: Academy of Taiwan Information Systems Research, Vol. 3, pp. 1-20.

Hudson, E.A. and Jorgenson, D.W. (1974), "US energy policy and economic growth, 1975-2000", The Bell Journal of Economics and Management Science, Vol. 5 No. 2, pp. 461-514.

IAEA (2009), IAEA Tools and Methodologies for Energy System Planning and Nuclear Energy System Assessments, Austria: International Atomic Energy Agency.

Iqbal, M. (1986), "Substitution of labour, capital and energy in the manufacturing sector of Pakistan”, Empirical Economics, Vol. 11 No. 2, pp. 81-95, available at: http://dx.doi.org/ 10.1007/BF01987506

Iyke, B.N. (2015), "Electricity consumption and economic growth in Nigeria: a revisit of the energygrowth debate", Energy Economics, Vol. 51, pp. 166-176, available at: http://dx.doi.org/10.1016/j. eneco.2015.05.024

Kavrakoğlu, I. (1981), Ülke Ekonomisinde Enerji Sorunu ve Çözüm Yollan, ISO, İstanbul, Yayın No: 8.

Koetse, M.J., De Groot, H.L. and Florax, R.J. (2008), "Capital-energy substitution and shifts in factor demand: a meta-analysis”, Energy Economics, Vol. 30 No. 5, pp. 2236-2251.

Krugman, P. and Wells, R. (2010), Microeconomics, Worth Publishers, New York, NY.

Liddle, B. (2012), "The importance of energy quality in energy intensive manufacturing: evidence from panel cointegration and panel FMOLS”, Energy Economics, Vol. 34 No. 6, pp. 1819-1825, available at: http://dx.doi.org/10.1016/j.eneco.2012.07.013

Mallick, H. (2007), "Does energy consumption fuel economic growth in India?”, Working Paper 388, India: Centre for Development Studies.

Mankiw, N.G. (2010), Macroeconomics, 7th ed., Worth Publishers, New York, NY.

Mehrara, M. (2007), "Energy consumption and economic growth: the case of oil exporting countries", Energy Policy, Vol. 35 No. 5, pp. 2939-2945, available at: http://dx.doi.org/10.1016/j. enpol.2006.10.018

Odhiambo, N.M. (2009), "Energy consumption and economic growth nexus in Tanzania: an ARDL bounds testing approach", Energy Policy, Vol. 37 No. 2, pp. 617-622, available at: http://dx.doi. org/10.1016/j.enpol.2008.09.077

Ozturk, I., Aslan, A. and Kalyoncu, H. (2010), "Energy consumption and economic growth relationship: evidence from panel data for low and middle income countries", Energy Policy, Vol. 38 No. 8, pp. 4422-4428, available at: http://dx.doi.org/10.1016/j.enpol.2010.03.071

Panayotou, T. (1993), Empirical Tests and Policy Analysis of Environmental Degradation at Different Stages of Economic Development, ILO: World Employment Programme Research, WEP 2-22/ WP. 238. 
Patterson, M.G. (1996), "What is energy efficiency?: Concepts, indicators and methodological issues", Energy Policy, Vol. 24 No. 5, pp. 377-390, available at: http://dx.doi.org/10.1016/0301-4215(96) 00017-1(96)00017-1

Pesaran, M.H. (2004), "General diagnostic tests for cross section dependence in panels", CESifo Working Papers No. 1233, IZA Discussion Paper No. 1240, Center for Economic Studies and Ifo Institute for Economic Research.

Pesaran, M.H. (2007), "A simple panel unit root test in the presence of cross-section dependence", Journal of Applied Econometrics, Vol. 22 No. 2, pp. 265-312, available at: http://dx.doi.org/ 10.1002/jae.951

Pesaran, M.H. and Smith, R. (1995), "Estimating long-run relationships from dynamic heterogeneous panels", Journal of Econometrics, Vol. 68 No. 1, pp. 79-113, available at: http://dx.doi.org/10.1016/ 0304-4076(94)01644-F

Pesaran, M.H., Shin, Y. and Smith, R.P. (1999), "Pooled mean group estimation of dynamic heterogeneous panels", Journal of the American Statistical Association, Vol. 94 No. 446, pp. 621-634, available at: http://dx.doi.org/10.1080/01621459.1999.10474156

Phillips, P.C.B. and Hansen, B.E. (1990), "Statistical inference in instrumental variables regression with I (1) processes", The Review of Economic Studies, Vol. 57 No. 1, pp. 99-125, available at: http://dx. doi.org/10.2307/2297545

Rivers, N. and Jaccard, M. (2006), "Useful models for simulating policies to induce technological change", Energy Policy, Vol. 34 No. 15, pp. 2038-2047, available at: http://dx.doi.org/10.1016/j. enpol.2005.02.003

Sarıcı, V. and Sohtaoğlu, N.H. (2012), “Avrupa birliği üyesi ülkeler ile Türkiye'deki yapisal gelişmelerin toplam nihai enerji yoğunluğuna etkileri”, Dünya Enerïi Konseyi Türk Milli Komitesi Türkiye 12, Enerji Kongresi, 14-16 Kasim.

Saunders, H.D. (1992), "The Khazzoom-Brookes postulate and neoclassical growth", The Energy Journal, Vol. 13 No. 4, pp. 131-148.

Schurr, S.H., Netschert, B.C., Eliasberg, V.F., Lerner, J. and Landsberg, H.H. (1960), Energy in the American Economy, 1850-1975: An Economic Study of its History and Prospects, Johns Hopkins Press, Baltimore, MD.

Shiu, A. and Lam, P.L. (2004), "Electricity consumption and economic growth in china", Energy Policy, Vol. 32 No. 1, pp. 47-54, available at: http://dx.doi.org/10.1016/S0301-4215(02)00250-1

Smulders, S. and De Nooij, M. (2003), “The impact of energy conservation on technology and economic growth", Resource and Energy Economics, Vol. 25 No. 1, pp. 59-79, available at: http://dx.doi.org/ 10.1016/S0928-7655(02)00017-9

Stern, D.I. (2000), "Multivariate cointegration analysis of the role of energy in the US macroeconomy", Energy Economics, Vol. 22 No. 2, pp. 267-283, available at: http://dx.doi.org/10.1016/S0140-9883(99)00028-6

Stern, D.I. (2004), "Economic growth and energy”, Encyclopaedia of Energy, Vol. 2, pp. 35-51.

Stern, D.I. (2010), "Energy quality”, Ecological Economics, Vol. 69 No. 7, pp. 1471-1478, available at: http://dx.doi.org/10.1016/j.ecolecon.2010.02.005

Stern, D.I. (2011), “The role of energy in economic growth”, Ecological Economics Reviews Annals of the New York Academic Science, Vol. 1219, pp. 26-51, available at: http://dx.doi.org/10.1111/j.17496632.2010.05921.x

Stern, D.I. and Cleveland, C.C. (2004), "Energy and economic growth", Rensselaer Working Papers in economics, No. 0410, pp. 1-41.

Stock, J.H. and Watson, M.W. (1993), "A simple estimator of cointegrating vectors in higher order integrated systems", Econometrica, Vol. 61 No. 4, pp. 783-820, available at: http://dx.doi.org/ $10.2307 / 2951763$

Tatoğlu, F.Y. (2012), İleri Panel Veri Analizi, Beta Yayınevi, Istanbul. 
Thompson, P. and Taylor, T.G. (1995), "The capital-energy substitutability debate: a new look", The Review of Economics and Statistics, Vol. 77 No. 3, pp. 565-569.

Webster, M., Paltsev, S. and Reilly, J. (2008), “Autonomous efficiency improvement or income elasticity of energy demand: does it matter?”, Energy Economics, Vol. 30 No. 6, pp. 2785-2798, available at: http://dx.doi.org/10.1016/j.eneco.2008.04.004

Westerlund, J. (2007), "Testing for error correction in panel data", Oxford Bulletin of Economics and Statistics, Vol. 69 No. 6, pp. 709-748, available at: http://dx.doi.org/10.1111/j.14680084.2007.00477.x

Yu, E.S.H. and Hwang, B.K. (1984), “The relationship between energy and GNP: further results”, Energy Economics, Vol. 6 No. 3, pp. 186-190, available at: http://dx.doi.org/10.1016/0140-9883(84)90015-X

\section{Corresponding author}

Ömer Esen can be contacted at: o.esen@alparslan.edu.tr

For instructions on how to order reprints of this article, please visit our website: 